$\mathrm{Y}-12$

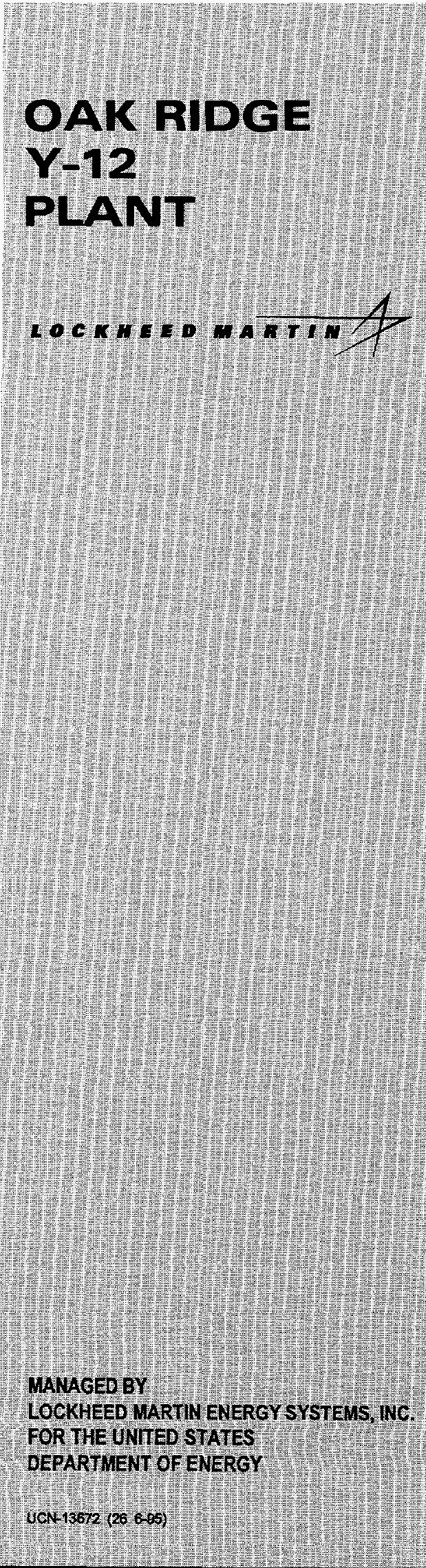

APR 301998

$$
\text { OSTI }
$$

Project Accomplishment Summary for

Project Number 94-Y12P-002-XX

\title{
ADVANCED PHYSICAL MODELS AND MONITORING METHODS FOR IN SITU BIOREMEDIATION
}

\author{
Ken Simon \\ Lockheed Martin Energy Systems, Inc. \\ Paul Chalmer \\ The National Center for Manufacturing Sciences
}

May 30, 1996

Approved for Public Release; distribution is unlimited.

Prepared by the

Oak Ridge Y-12 Plant

managed by

LOCKHEED MARTIN ENERGY SYSTEMS, INC.

for the

U.S. DEPARTMENT OF ENERGY

under contract DE-AC05-84OR21400

DISTRIBUTION OF THIS DOCUMENT IS UNLIMTED LN MASTER 


\section{DISCLAIMER}

Portions of this document may be illegible electronic image products. Images are produced from the best available original document. 


\section{PROJECT ACCOMPLISHMENTS SUMMARY}

Title:

Project Number:

CRADA Number:

Partner:
Advanced Physical Models and Monitoring Methods for In Situ Bioremediation

94-Y12P-002-XX

PES003-0077

The National Center for Manufacturing Sciences

\section{BACKGROUND}

Numerous reports have indicated that contamination at DOE facilities is widespread and pervasive. Existing technology is often too costly or ineffective in remediating these contamination problems. An effective method to address one class of contamination, petroleum hydrocarbons, is in situ bioremediation. This project was designed to provide tools and approaches for increasing the reliability of in situ bioremediation.

An example of the recognition within DOE for developing these tools is in the FY-1995 Technology Development Needs Summary of the Office of Technology Development of the US $D O E$. This document identifies specific needs addressed by this research. For example, Section 3.3 Need Statement IS-3 identifies the need for a "Rapid method to detect in situ biodegradation products." Also, BW-1 identifies the need to recognize boundaries between clean and contaminated materials and soils. Metabolic activity could identify these boundaries.

Measuring rates of in situ microbial activity is critical to the fundamental understanding of subsurface microbiology and in selecting natural attenuation as a remediation option. Given the complexity and heterogeneity of subsurface environments, a significant cost incurred during bioremediation is the characterization of microbial activity, in part because so many intermediate end points (biomass, gene frequency, laboratory measurements of activity, etc.) must be used to infer in situ activity. A fast, accurate, real-time, and cost-effective method is needed to determine success of bioremediation at DOE sites.

\section{DESCRIPTION}

This CRADA sought to develop new understanding and better tools to stimulate and optimize in situ bioremediation of hydrocarbon contaminants in subsurface environments. Program elements included (1) new approaches to overcoming hydrogeochemical limitations to introduction of reagents, (2) advanced computer modeling of hydrogeochemical and microbiological processes, (3) development and application of biosensors/bioreporters for optimization and monitoring of bioremediation, and (4) development of innovative instrumentation to measure the functioning of microbial communities at bioremediation field sites. The principal thrust of the work revolved around field studies at an experimental research site developed by the National Center for Manufacturing Sciences (NCMS) and NESA \& Associates, Inc. The initial site characterization demonstrated a relationship between the spatial distribution of hydrocarbon contamination in the aquifer, controlling geochemical variables, and the structure and function of microbial communities. Unfortunately, the CRADA was terminated before the more significant observations could be made on the success of manipulative interventions in optimizing 
bioremediation. Other components of the CRADA that were not as directly tied to the field research were more successful in completing their objectives. Biosensors/bioreporters were developed to respond to key processes and conditions relevant to subsurface bioremediation, including bioreporters of nutrient limitations, and a series of bioreporters that function under low-oxygen conditions. In addition, significant progress was made in demonstrating proof-ofprinciple for development of an innovative detector to quantify radioactive peaks eluting from a gas chromatograph. Work on this CRADA is the basis for three patent disclosures.

\section{BENEFITS TO DOE}

Proof-of-principle of the two major tools proposed as part of this project was achieved during the shortened project lifetime. These tools would have proved to be significant benefits to DOE as they moved from proof-of-principle to implementation. However, funding from this CRADA is no longer available to complete that process.

The new GC solid scintillation counter will provide a tool that will significantly increase the effectiveness of bioremediation monitoring for in situ activity. Researchers have completed scoping experiments and a draft of an invention disclosure for this system. Completion of a prototype was planned, but will not be accomplished due to the early termination of the project. This will likely significantly delay the use of this technology for the benefit of DOE.

A similar situation exists for use of the GFP bioreporters. Researchers have proven the utility for GFP bioreporters in scoping experiments and they are being used in studies of bacterial transport that will help with evaluation of the potential for bioaugmentation as an approach to bioremediation. They also have potential in evaluating microbial activity in low-oxygen zones common to DOE petroleum-contaminated sites. However, with in the reduced time frame of the project, researchers were not able to complete that portion of the research.

Researchers have also proved, in laboratory and modeling studies, the potential for using nitrate as an electron acceptor in remediating petroleum-contaminated sites. This approach could significantly increase the remediation of contaminated aquifers as the use of nitrate and oxygen can significantly increase the supply of electron acceptors over that of oxygen alone. Although researchers had hoped to demonstrate this in the field, but were unable to do so, they did show that the approach is sound. Thus, the potential benefits to DOE are significant in reducing remediation time for low-oxygen sites.

\section{ECONOMIC IMPACT}

Results were beginning to indicate the economic advantages of multiple electron acceptors in promoting in situ hydrocarbon degradation. If this had been pursued, it would have had a very large impact on both the industrial and Federal sites with these problems.

\section{PROJECT STATUS}

This project has been terminated, effective May 5, 1996.

\section{DOE FACILITY POINTS OF CONTACT FOR PROJECT INFORMATION}




\begin{tabular}{|c|c|c|c|c|}
\hline NAME & RESPONSIBILITY & ADDRESS & $\begin{array}{l}\text { PHONE } \\
\text { NUMBER }\end{array}$ & $\begin{array}{c}\text { FAX } \\
\text { NUMBER }\end{array}$ \\
\hline R. S. Burlage & $\begin{array}{l}\text { Molecular biology and } \\
\text { biosensor Development }\end{array}$ & $\begin{array}{l}\text { LMES/ORNL } \\
\text { P.O. Box } 2008 \\
\text { MS 6036, Bldg. } 1505 \\
\text { Oak Ridge, TN } 37831\end{array}$ & $423-574-7321$ & $423-576-8543$ \\
\hline J. L. Cochran & $\begin{array}{l}\text { Design and testing of } \\
\text { improved GC } \\
\text { radioactivity detector }\end{array}$ & $\begin{array}{l}\text { LMES/Y-12 Plant } \\
\text { P. O. Box } 2009 \\
\text { MS 8084, Bldg. } 9203 \\
\text { Oak Ridge, TN } 37831\end{array}$ & $423-574-7321$ & $423-576-2782$ \\
\hline J. F. McCarthy & $\begin{array}{l}\text { ORNL PI in charge of } \\
\text { Hydrogeochemical tasks }\end{array}$ & $\begin{array}{l}\text { LMES/ORNL } \\
\text { P.O. Box } 2008 \\
\text { MS 6036, Bldg. } 1505 \\
\text { Oak Ridge, TN } 37831\end{array}$ & $423-576-606$ & $423-576-3989$ \\
\hline $\begin{array}{l}\text { A. V. } \\
\text { Palumbo }\end{array}$ & $\begin{array}{l}\text { ORNL PI in charge of } \\
\text { microbiological work }\end{array}$ & $\begin{array}{l}\text { LMES/ORNL } \\
\text { P.O. Box } 2008 \\
\text { MS 6036, Bldg. } 1505 \\
\text { Oak Ridge, TN } 37831\end{array}$ & $423-576-8002$ & $423-576-8543$ \\
\hline S. M. Pfiffner & $\begin{array}{l}\text { Microbial community } \\
\text { characterization }\end{array}$ & $\begin{array}{l}\text { LMES/ORNL } \\
\text { P.O. Box } 2008 \\
\text { MS 6036, Bldg. } 1505 \\
\text { Oak Ridge, TN } 37831\end{array}$ & $423-574-7290$ & $423-576-3989$ \\
\hline T. J. Phelps & $\begin{array}{l}\text { Microbial community } \\
\text { characterization }\end{array}$ & $\begin{array}{l}\text { LMES/ORNL } \\
\text { P.O. Box } 2008 \\
\text { MS 6036, Bldg. } 1505 \\
\text { Oak Ridge, TN } 37831\end{array}$ & $423-574-7290$ & $423-576-3989$ \\
\hline K. F. Simon & $\begin{array}{l}\text { Y-12 PI - Management } \\
\text { Oversight }\end{array}$ & $\begin{array}{l}\text { LMES/Y-12 Plant } \\
\text { P. O. Box } 2009 \\
\text { MS 8084, Bldg. } 9203 \\
\text { Oak Ridge, TN } 37831\end{array}$ & $423-576-5525$ & $423-576-6986$ \\
\hline
\end{tabular}

\section{COMPANY SIZE AND POINTS OF CONTACT}

National Center for Manufacturing Sciences, Paul Chalmer, 3025 Boardwalk Drive, Ann Arbor, MI, 48108-3266

\section{PROJECT EXAMPLES}

See attached photographs of bioluminescent bioreporter bacteria and sketch of position-sensitive scintillation detector.

\section{TECHNOLOGY COMMERCIALIZATION}

Four patent disclosures are being submitted based on work performed in this CRADA. Three disclosures are related to bioreporter development and one is related to the radioactivity detector 
for gas chromatography.

The patent disclosure related to development of a radioactivity detector for chromatographic applications has significant commercialization potential. Researchers will contact chromatographic instrumentation companies to explore possibilities of further development toward commercialization. Private industry has also expressed an interest in bioreporter technology developed, in part, during work within this CRADA. The principal thrust of the CRADA was, however, to develop new and improved techniques for in situ bioremediation that could be transferred to industry. Because of the termination of the CRADA, this expected commercial product was not achieved. 


\section{ORNL-Photo $881-95$}

The petri dish on the right contains wild-type bacteria; the strain on the left is the same, except that it has been mutagenized with Tn5GFP1, a transposon constructed in our laboratory. The insertion of this transposon gives the bacteria a bright fluorescence, which is clearly seen in this photo taken of the plates on top of a UV light box. The fluorescence makes the cells easy to track and detect in complex media, such as soils.

R. S. Burlage 

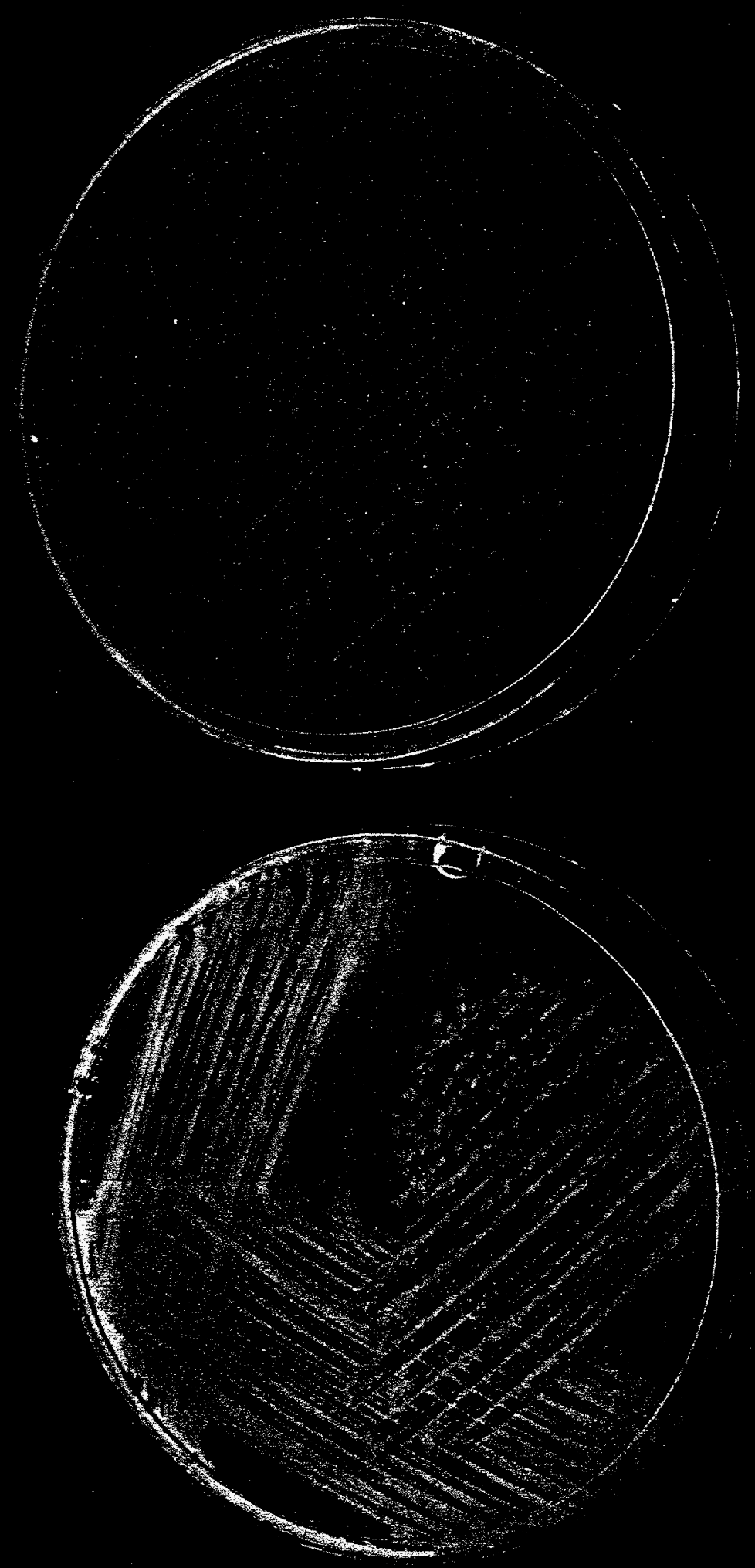
Bioluminescent bioreporter bacteria are growing in a bioreactor that has been fed 1 micromolar toluene. The bacteria are actively degrading the toluene, as evidenced by the intense bioluminescence seen in the photograph. All the light that was used to take this picture emanates from the bacteria themselves. The production of visible light allows the study of gene expression under in situ conditions.

R. S. Burlage 


\section{Position Sensitive Scint illation Detector \\ Scintillator}

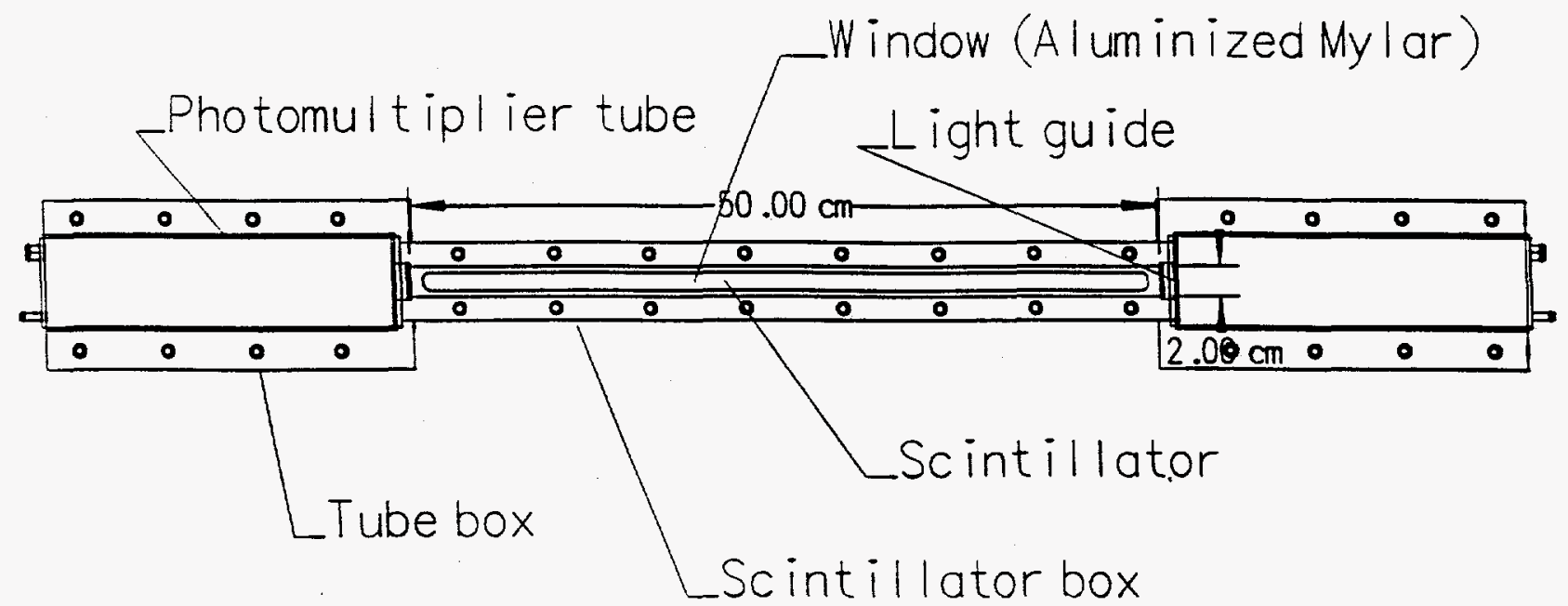

Segment Test Unit

Scintillator (see blown up drawing of head)

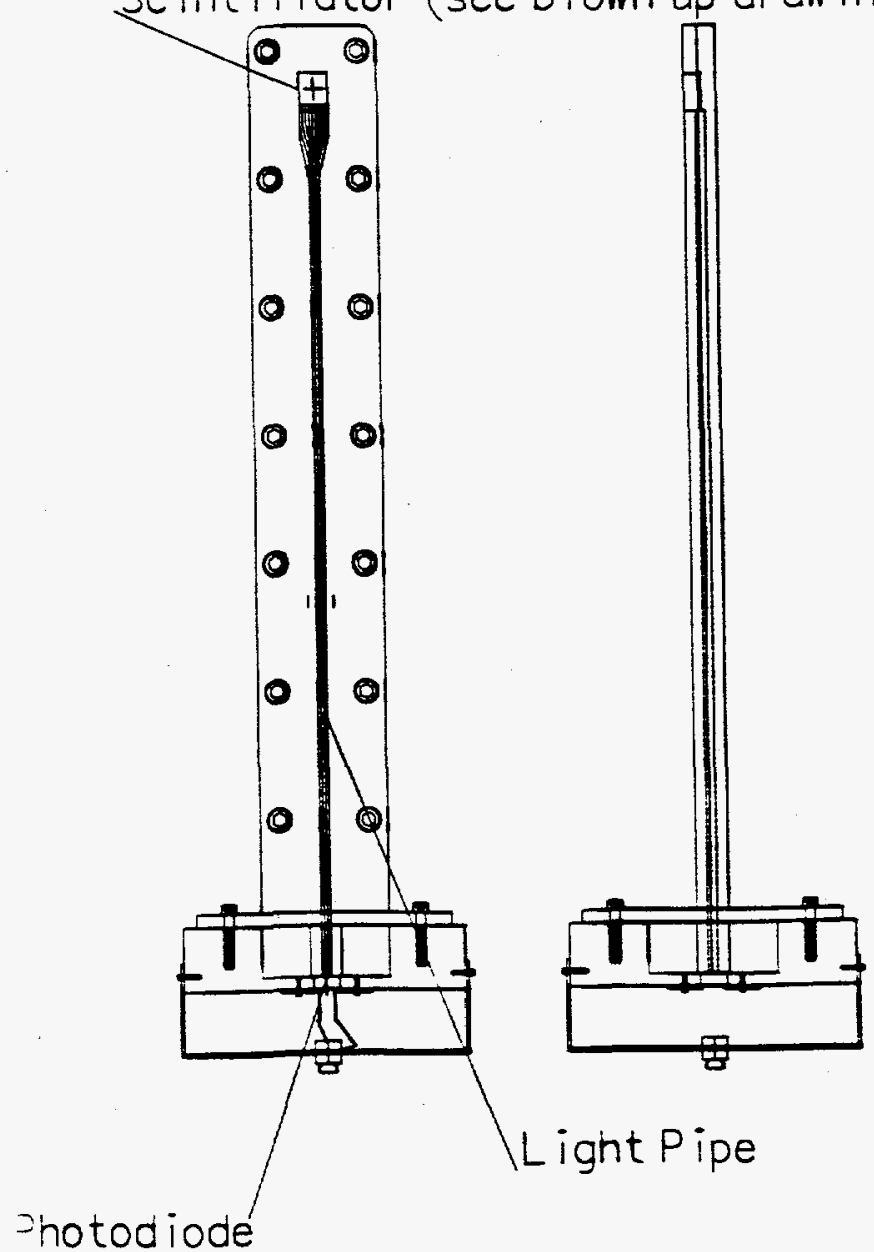

Probe with Photomultipl ier Tube

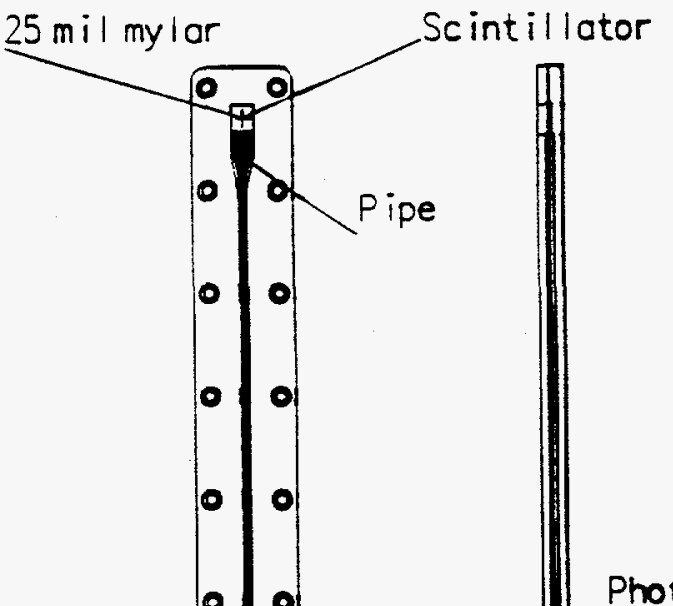

Photomul t ipl ier Tut

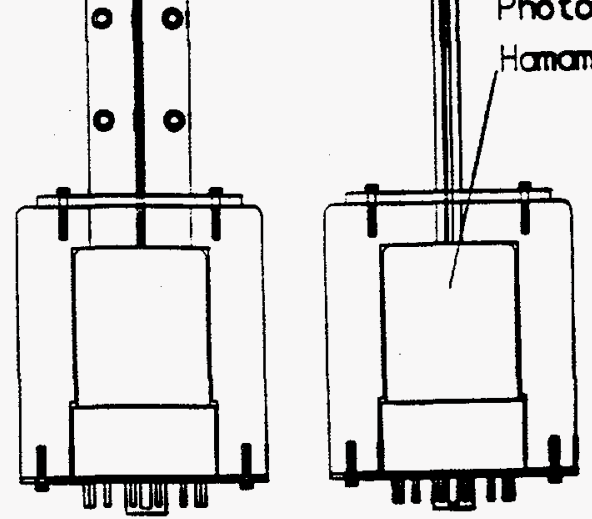

Detector us ing APD 


\section{DISTRIBUTION}

Ken Simon, MS 8094, 9202

Ray Ford, MS 8084, 9203

Joyce Shepherd, MS 6416, 5002

Andy Stevens/DOE OR, MS 8009, 9704-2

Diane Bird/DOE DP-17

Bill Wilburn, MS 8015, 9704-2

Lab Records, MS 6285, 5400-N

Y-12 Central Files, MS 8169, 9711-5 (3 copies)

Paul Chalmer, National Center for Manufacturing Sciences, 3025 Boardwalk Drive, Ann Arbor, MI, 48108-3266 (5 copies) 